\title{
Analisis Pengaruh Rasio Keuangan dan Ukuran Aset Pada Pertumbuhan Laba Perusahaan Manufaktur Yang Terdaftar Pada Bursa Efek Indonesia Periode 2010-2013

\author{
The Influence of Financial Ratios and Asset Size on Earning Growth of \\ Manufacture Companies Listed in the Indonesia Stock Exchange 2010-2013
}

\author{
Dian Permata Sari, Hadi Paramu ${ }^{1}$, Elok Sri Utami \\ Jurusan Manajemen, Fakultas Ekonomi dan Bisnis, Universitas Jember \\ Jln. Kalimantan 37, Jember 68121 \\ hadi.fe@unej.ac.id
}

\begin{abstract}
Abstrak
Artikel ini bertujuan untuk menganalisis pengaruh rasio keuangan dan ukuran aset terhadap pertumbuhan laba pada perusahaan manufaktur. Sebanyak 60 perusahaan dari populasi perusahaan manufaktur yang terdaftar di Bursa Efek Indonesia pada 20102013 dijadikan sampel dengan menggunakan simple random sampling. Metode analisis data yang digunakan adalah analisis regresi linear berganda. Hasil analisis menunjukkan bahwa secara parsial hanya Return on Assets yang berpengaruh signifikan terhadap pertumbuhan laba, sedangkan current ratio, total assets turnover, debt ratio, earning per share dan variabel dummy (golongan aset) tidak berpengaruh terhadap pertumbuhan laba. Hasil ini menginformasikan bahwa pertumbuhan laba perusahaan bisa diindikasi oleh Return on Assets sedangkan rasio keuangan lainnya dan ukuran aset tidak mampu memberikan sinyal pertumbuhan laba perusahaan.
\end{abstract}

Kata Kunci: current ratio, total assets turnover, debt ratio, return on assets, earning per share, pertumbuhan laba

\begin{abstract}
This article aims to analyze the influence of financial ratios and asset size on the earning growth of manufacture companies. 60 manufature companies listed in the Indonesia Stock Exchange in 2010-2013 were selected as samples.using simple random sampling method. Data analysis method used was multiple linear regression analysis. The results showed that only partially Return on Assets influences the earning growth, while the current ratio, total asset turnover, debt ratio, earnings per share and a dummy variable (asset classes) do not influence on earning growth. This informs that the company's earning growth could be indicated by Return on Assets while other financial ratios and asset size could not provide a signal for company's earning grwoth.
\end{abstract}

Keywords: current ratio, total assets turnover, debt ratio, return On Assets, earning per share, , earnings growth

\section{Pendahuluan}

Laporan keuangan berisi ringkasan kegiatan yang menyediakan data keuangan perusahaan. Data dalam laporan keuangan masih relatif mentah. Untuk mendapatkan informasi mengenai kinerja keuangan perusahaan, posisi keuangan, kegiatan operasi, serta perubahan posisi keuangan perusahaan, maka data tersebut harus diolah terlebih dahulu sesuai dengan kebutuhan informasi keuangan perusahaan tersebut. Informasi yang terdapat dalam laporan keuangan harus relevan agar dapat membantu para pemakainya dalam proses pengambilan keputusan, ini berarti bahwa informasi tersebut dapat mempengaruhi keputusan ekonomi pemakai dengan membantu mereka dalam mengevaluasi peristiwa masa lalu, masa kini, atau masa yang akan datang, menegaskan atau mengkoreksi hasil evaluasi mereka di masa lalu.

Kinerja perusahaan sering diukur dari laba yang dapat dihasilkan oleh perusahaan. Informasi tentang pertumbuhan laba seringkali diperlukan dalam membuat keputusan perusahaan. Informasi tersebut sangat bermanfaat baik untuk pihak internal (manajer keuangan perusahaan), ataupun pihak

1 Corresponding Author

e-Journal Ekonomi Bisnis dan Akutansi, 2017, Volume IV (1) : 63 - 66 eksternal seperti investor, kreditor, pemasok, pelanggan, dan lembaga pemerintah.

Prediksi pertumbuhan laba diperlukan karena pertumbuhan laba perusahaan pada masa yang akan datang tidak dapat dipastikan. Prediksi ini dapat dilakukan dengan menggunakan rasio keuangan perusahaan sebagai prediktor. Brigham dan Houston (2013:133) menyatakan bahwa analisis laporan keuangan berguna untuk membantu mengantisipasi kondisi masa depan termasuk meramalkan laba, dan juga sebagai titik awal untuk merencanakan tindakan-tindakan yang akan memperbaiki kinerja di masa depan. Rasio keuangan dikelompokkan menjadi lima kategori yaitu rasio likuiditas, rasio aktivitas, rasio solvabilitas, rasio profitabilitas, dan rasio pasar Weston dan Brigham (1985:57) .

Kajian mengenai prediksi pertumbuhan (perubahan) laba telah dilakukan oleh beberapa peneliti yang menghasilkan temuan yang berbeda. Warsidi dan Pramuka (2000) menemukan rasio Working Capital to Total Assets berpengaruh signifikan terhadap pertumbuhan laba. Epri (2007) menyimpulkan bahwa rasio Working Capital to Total Assets tidak berpengaruh signifikan terhadap pertumbuhan laba. Kajian oleh Epri (2007) dan Ade dan Sri (2013) menunjukkan bahwa Total Assets Turnover berpengaruh 
signifikan terhadap pertumbuhan laba, sedangkan Supriatmi dan Wahyudin (2006) menunjukkan bahwa Total Assets Turnover menyatakan hal yang sebaliknya. Kajian oleh Meythi (2005) dan Ade dan Sri (2013) menunjukkan bahwa Inventory Turnover berpengaruh signifikan terhadap pertumbuhan laba sedangkan kajian Widiasih (2006) menunjukkan hal yang sebaliknya.

Hasil kajian empiris tersebut menunjukkan bahwa rasio keuangan bisa mempengaruhi dan tidak mempengaruhi pertumbuhan laba perusahaan. Kondisi ini menunjukkan bahwa pemodelan untuk memprediksi pertumbuhan laba masih diperlukan. Model prediksi yang dikembangkan seharusnya tidak terfokus pada rasio keuangan saja tetapi juga ukuran aset perusahaan. Artikel bertujuan untuk menganalisis pengaruh rasio keuangan (current ratio, total assets turnover, debt ratio, return on assets, earning per share) dan ukuran aset perusahaan secara parsial dan simultan terhadap pertumbuhan laba perusahaan manufaktur yang terdaftar di BEI periode 2010-2013.

\section{Metode}

\section{Rancangan Penelitian}

Penelitian ini menggunakan pendekatan kuantitatif. Jenis penelitian ini merupakan explanatory research.

\section{Jenis dan Sumber Data}

Jenis data yang digunakan dalam penelitian ini adalah data kuantitatif, yaitu hasil perhitungan rasio keuangan dari laporan keuangan tahunan perusahaan manufaktur periode 2010-2013 yang telah diaudit dan dipublikasikan melalui situs resmi Bursa Efek Indonesia.

\section{Populasi dan Sampel}

Populasi dalam penelitian ini adalah perusahaan manufaktur yang terdaftar di Bursa Efek Indonesia selama periode 20102013. Sebanyak 60 perusahaan dipilih dengan menggunakan teknik simple random sampling.

\section{Metode Analisis Data}

Variabel yang dikaji meliputi variabel dependen dan variabel independen. Variabel dependen yang dikaji adalah pertumbuhan laba perusahaan $i$ pada periode $t+1\left(\mathrm{LABA}_{\mathrm{it}+1}\right)$. Variabel independennya adalah (a) Current Ratio perusahaan $i$ pada periode $t\left(\mathrm{Cr}_{\mathrm{it}}\right)$, (b) Total Assets Turnover perusahaan $i$ pada periode $t$ ( TAT $\left._{\mathrm{it}}\right)$, (c) Debt Ratio perusahaan $i$ pada periode $t$ (Drit), (d) Return on Assets perusahaan $i$ pada periode $t\left(R O A_{i t}\right)$, (e) Earning per Share perusahaan $i$ pada periode $t\left(\mathrm{EPS}_{\mathrm{it}}\right)$, (f) variabel dummy D1 (bernilai 1 untuk aset kecil dan 0 untuk aset sedang dan aset besar), dan (g) variabel dummy D2 (bernilai 1 untuk aset sedang dan 0 untuk aset kecil dan aset besar).

Metode analisis data yang digunakan adalah analisis regresi linear berganda dengan bentuk sebagai berikut:

$$
\mathrm{LABA}_{\mathrm{it}+1}=\mathrm{f}\left(\mathrm{Cr}_{\mathrm{it}}, \mathrm{TAT}_{\mathrm{it}}, \mathrm{DR}_{\mathrm{it}}, \mathrm{ROA}_{\mathrm{it}}, \mathrm{EPS}_{\mathrm{it}}, \mathrm{D} 1, \mathrm{D} 2\right)
$$

Uji $\mathrm{t}$ dan uji $\mathrm{F}$ digunakan menguji signifikansi pengaruh variabel independen (current ratio, total assets turnover, debt rati, return on assets, earning per share dan variabel dummy) secara parsial dan secara simultan terhadap pertumbuhan laba perusahaan manufaktur.

\section{Hasil dan Pembahasan}

Gambaran tingkat pertumbuhan laba, current ratio, total assets turnover, debt ratio, return on assets, earning per share pada perusahaan manufaktur disajikan pada Tabel 1 berikut ini.

Tabel 1. Deskripsi Statistik Data Sampel Perusahaan

\begin{tabular}{rrrrrr}
\hline Tahun & Min & Maks & Rata-rata & $\begin{array}{r}\text { Deviasi } \\
\text { Standar }\end{array}$ & $\begin{array}{c}\text { Koefisien } \\
\text { Variasi }\end{array}$ \\
\hline \multicolumn{5}{c}{ Pertumbuhan Laba (\%) } \\
2010 & $-25,13$ & 4,90 & $-0,16$ & 3,64 & 22,48 \\
2011 & $-70,20$ & 38,16 & 0,0072 & 10,98 & 1532,90 \\
2012 & $-85,65$ & 4,83 & $-1,3167$ & 11,20 & 8,51 \\
2013 & $-3,16$ & 3,45 & $-0,1843$ & 1,12 & 6,11 \\
\hline
\end{tabular}

Current Ratio (\%)

\begin{tabular}{|c|c|c|c|c|c|}
\hline 2010 & 4,59 & 872 & 206,27 & 188,59 & 0,91 \\
\hline 2011 & 10 & 751,50 & 201,38 & 175,41 & 0,87 \\
\hline 2012 & 11 & 934 & 214,03 & 172,47 & 0,81 \\
\hline 2013 & 2,71 & 672,80 & 193,53 & 147,08 & 0,76 \\
\hline \multicolumn{6}{|c|}{ Total Asset Turn Over (\%) } \\
\hline 2010 & 4 & 345 & 111,43 & 62,95 & 0,56 \\
\hline 2011 & 3,40 & 422 & 112,47 & 72,37 & 0,64 \\
\hline 2012 & 5,54 & 350 & 106,72 & 67,91 & 0,63 \\
\hline 2013 & 1,50 & 374 & 104,54 & 73,22 & 0,70 \\
\hline \multicolumn{6}{|c|}{ Debt Ratio (\%) } \\
\hline 2010 & 0,04 & 234,10 & 60,17 & 43,45 & 0,72 \\
\hline 2011 & 4,78 & 608,11 & 64,28 & 79,67 & 1,23 \\
\hline 2012 & 3,95 & 243,23 & 57,83 & 39,95 & 0,69 \\
\hline 2013 & 6,52 & 255,40 & 54,93 & 38,35 & 0,70 \\
\hline \multicolumn{6}{|c|}{ Return on Assets (\%) } \\
\hline 2010 & $-61,85$ & 38,95 & 5,99 & 14,63 & 2,44 \\
\hline 2011 & $-67,01$ & 41,65 & 6,90 & 16,01 & 2,31 \\
\hline 2012 & $-10,72$ & 40,38 & 8,31 & 11,89 & 1,43 \\
\hline 2013 & $-34,59$ & 66,91 & 6,48 & 14,58 & 2,24 \\
\hline \multicolumn{6}{|c|}{ Earning per Share (Rp) } \\
\hline 2010 & -2.234 & $2.102,1$ & 957,29 & $3.211,86$ & 3,35 \\
\hline 2011 & -7.061 & $2.407,4$ & $1.021,01$ & $3.944,41$ & 3,86 \\
\hline 2012 & -3.435 & $2.151,6$ & $1.035,39$ & $3.683,10$ & 3,55 \\
\hline 2013 & -3.380 & $5.557,6$ & $1.657,96$ & $7.716,64$ & 4,65 \\
\hline
\end{tabular}


Pertumbuhan laba pada perusahaan manufaktur mengalami fluktuasi secara rata-rata. Deviasi standar deviasi terus cenderung berfluktuasi sedang koefisien variasinya cenderung menurun. Hal ini mengindikasikan bahwa variabilitas pertumbuhan laba cenderung semakin berkurang pada 2010 2013.

Tren rata-rata Current Ratio cenderung menurun. Hal ini mengindikasikan tingkat likuiditas perusahaan relatif menurun. Namun demikian, penurunan rasio ini tidak bermakna perusahaan dalam kondisi tidak likuid karena nilai rata-rata rasio ini masih lebih besar dari $100 \%$. Pergerakan tren standar deviasi dan koefisien variasi relatif menurun. Hal ini variabilitas dari likuiditas perusahaan relatif menurun.

Pergerakan tren Total Assest Turnover secara rata-rata relatif menurun namun perputarannya relatif baik. Tren deviasi bersifat signifikan, kecuali variabel ROA dan secara simultan varaibel independen dalam model berpengaruh signifikan (pada tingkat signifikansi 1\%) terhadap pertumbuhan laba perusahaan manufaktur. Nilai $\mathrm{R}^{2}$ dari model tersebut adalah 0,053 . Hal tersebut menunjukkan bahwa 5,3\% dari variasi pertumbuhan laba mampu dijelaskan secara bersama-sama oleh current ratio, total assets turnover, debt ratio, return on assets, eaning per share, dummyl, dummy2 dan sisanya sebesar 94,7\% merupakan pengaruh faktor-faktor lain yang tidak dijelaskan oleh model regresi ini.

\section{Pembahasan}

\section{Pengaruh Current Ratio terhadap Pertumbuhan Laba}

Hasil penelitian menunjukkan bahwa variabel Current Ratio tidak berpengaruh terhadap pertumbuhan laba. Hal ini berarti bahwa Current Ratio tidak dapat digunakan untuk

$$
\begin{aligned}
& \mathrm{ZLABA}_{\text {it }}=0,330+0,011 \mathrm{ZCR}_{\mathrm{it}}-0,018 \mathrm{ZTAT} \text { it }-0,005 \mathrm{DR}_{\mathrm{it}}+0,251 \mathrm{ZROA}_{\mathrm{it}}-0,112 \mathrm{ZEPS}-0,173 \mathrm{D} 1-0,023 \mathrm{D} 2+\mathrm{e}_{\mathrm{it}} \\
& (0,109)^{\text {ts }} \quad(0,878)^{\text {ts }} \quad(-0,793)^{\text {ts }} \quad(-1,105)^{\text {ts }} \quad(0,005)^{* * *} \quad(-1,155)^{\text {ts }} \quad(-0,275)^{\text {ts }} \quad(-0,885)^{\text {ts }}
\end{aligned}
$$

$$
\begin{aligned}
\mathrm{R}^{2} & =0,053 \quad \mathrm{~F}_{\text {hitung }}=2,925 * * * \\
\text { Keterangan: } * * * & =\text { signifikansi pada } \alpha=1 \% \text { ts }=\text { tidak signifikan }
\end{aligned}
$$

standar dan koefisien variasi Total Assest Turnover relatif meningkat. Ini mengindikasikan adanya perbedaan (variabilitas) Total Assest Turnover yang semakin besar antara perusahaan manufaktur pada periode kajian.

Tren nilai rata-rata, deviasi standar, dan koefisien variasi Debt Ratio relatif menurun. Hal ini menggambarkan bahwa proporsi hutang dalam modal perusahaan secara rata-rata menurun. Di sisi lain, variabilitas besarnya hutang dalam modal antarperusahaan cenderung semakin berkurang.

Tren rata-rata Return on Asset relatif meningkat pada periode yang dikaji. Ini berarti bahwa kemampuan untuk menghasilkan laba dari perusahaan yang menjadi sampel semakin meningkat. Deviasi standar dan koefisien variasi dari variabel ini menunjukkan pola yang relatif stabil. Hal menginformasikan bahwa perbedaan dalam kemampuan untuk menghasilkan laba antarperusahaan relatif sama dari tahun ke tahun.

Earning Per Share relatif meningkat pada periode kajian baik secara rata-rata, deviasi standar, dan koefisien variasinya. Hal ini mengindikasikan bahwa secara rata-rata kinerja perusahaan dari persepektif pasar semakin baik. Sebaran variasi Earning per Share semakin meningkat yang menunjukkan bahwa performa EPS relatif semakin heterogen antarperusahaan.

\section{Hasil Analisis Data}

Hasil uji normalitas data pada rasio keuangan yang dianalisis menunjukkan bahwa data rasio keuangan selama periode penelitian tidak berdistribusi normal. Berkaitan dengan hasil ini, data pada rasio keuangan tersebut ditransfomasikan dalam bentuk standar (standardized variable). Model regresi yang diestimasi berdasarkan hasil transformasi (diindikasikan oleh adanya huruf $\mathrm{Z}$ di depan simbol variabel) ditunjukkan pada persamaan berikut ini.

Persamaan tersebut menunjukkan bahwa secara parsial semua variabel independen dalam model yang dikembangkan tidak memprediksi pertumbuhan laba perusahaan manufaktur. Data pada Tabel 1 menunjukkan bahwa likuiditas perusahaan relatif baik. Artinya, aset lancar yang tersedia cukup untuk membayar kewajiban lancar perusahaan sehingga tidak mengganggu pelunasan utang lancar dan operasi perusahaan (Agus, 1995:105). Hasil ini secara teoretis dapat dijustifikasi. Likuiditas perusahaan tidak menjamin pertumbuhan laba perusahaan akan meningkat karena semakin banyak perusahaan menyimpan kas di tangan (cash on hand), berarti semakin banyak pula dana menganggur (Moeljadi, 2006:49). Di sisi lain, aset lancar didominasi juga oleh persediaan, baik persediaan bahan baku, barang dalam proses, maupun barang jadi, yang menambah nilai $\mathrm{CR}$ perusahaan tetapi tidak menghasilkan laba. Hasil ini memberikan informasi bagi manajer keuangan perusahaan manufaktur bahwa CR tidak memberikan dampak secara signifikan pada pertumbuhan laba. Dengan kata lain, CR perusahaan tidak dapat dijadikan sinyal pertumbuhan laba perusahaan.

\section{Pengaruh Total Assets Turnover terhadap Pertumbuhan Laba}

Hasil penelitian menunjukkan bahwa Total Assets Turnover tidak berpengaruh terhadap pertumbuhan laba perusahaan manufaktur. Hasil ini memberikan informasi kepada manajer keuangan perusahaan manufaktur bahwa tinggi rendahnya Total Assets Turnover tidak berdampak pada pertumbuhan laba perusahaan karena ada kemungkinan tingkat penjualan yang tinggi disertai dengan biaya operasional yang tinggi pula. Oleh karena itu, manajer keuangan harus lebih memperhatikan efisiensi biaya yang dikeluarkan perusahaan dalam menciptakan penjualan agar laba perusahaan dapat ditingkatkan.

\section{Pengaruh Debt Ratio terhadap Pertumbuhan Laba}

Hasil penelitian menunjukkan bahwa Debt Ratio tidak berpengaruh terhadap pertumbuhan laba perusahaan manufaktur. Hasil ini memberikan implikasi bahwa tingkat Debt Ratio tidak berdampak secara langsung pada pertumbuhan laba. Salah satu alasan yang bisa menjelaskan 
mengapa hasil ini bisa diperoleh adalah bahwa liabilitas jangka panjang (yang menjadi komponen dari Debt Ratio) tidak berjatuh tempo pada periode $(t+1)$. Secara teoretis, liabilitas tersebut memiliki jatuh tempo pada masa lebih dari satu tahun. Dengan demikian, karena liabilitas tersebut belum jatuh tempo, tingkat Debt Ratio relatif tidak berubah. Akibatmya, tingkat Debt Ratio tidak berpengaruh signifikan terhadap pertumbuhan laba perusahaan.

\section{Pengaruh Return on Assets terhadap Pertumbuhan Laba}

Hasil penelitian menunjukkan bahwa Return on Assets berpengaruh positif terhadap pertumbuhan laba perusahaan manufaktur. Hal ini berarti semakin tinggi tingkat Return on Assets pada periode t semakin tinggi tingkat pertumbuhan laba menjelaskan mengenai kemampuan perusahaan dalam memanfaatkan seluruh aktivanya dalam menghasilkan laba bersih. ROA tinggi berarti bahwa perusahaan menggunakan aktiva yang dimiliki secara efektif sehingga laba perusahaan dapat meningkat. Hasil penelitian ini didukung oleh teori yang dikemukakan (Brigham dan Houston, 2013:148) yang menyatakan bahwa jika ROA yang tinggi maka perolehan laba perusahaan juga tinggi.

\section{Pengaruh Earning per Share terhadap Pertumbuhan Laba}

Hasil penelitian menunjukkan bahwa Earning per Share tidak berpengaruh terhadap pertumbuhan laba. Hasil ini memberikan informasi kepada para manajer keuangan perusahaan manufaktur bahwa Earning per Share tidak berdampak terhadap pertumbuhan laba. Begitu juga untuk para investor dalam mengambil keputusan berinvestasi pada perusahaan manufaktur, tidak dapat menggunakan EPS sebagai alat prediksi pertumbuhan laba di masa mendatang. Secara teoretis, hasil ini bisa disebabkan oleh alokasi keuntugan perusahaan untuk pembayaran dividen, baik untuk pemegang saham preferen maupun saham biasa perusahaan. Dengan kata lain, jumlah keuntungan yang plowed-back atau direinvestasi relatif kecil sehingga nilai earning after taxes relatif kecil pula. Akibatnya, nilai Earning per Share juga relatif tidak bervariasi sehingga tidak dapat menjadi prediktor yang baik untuk pertumbuhan laba.

\section{Pengaruh Variabel Dummy (golongan aset) terhadap Pertumbuhan Laba}

Hasil analisis menunjukkan bahwa semua variabel dummy secara statistik tidak signifikan, yang berarti tidak ada pengaruh golongan aset terhadap pertumbuhan laba perusahaan manufaktur. Aset yang lebih besar tidak menjamin peningkatan pertumbuhan laba, dan sebaliknya. Secara teoretis, hal ini terjadi jika aset tersebut dibiayai dari utang. Perusahaan harus membayar beban bunga pinjaman sebagai biaya utang. Besarnya beban bunga (biaya utang) yang dibayarkan bisa menyebabkan perolehan laba relatif stabil.

\section{Simpulan}

Hasil analisis data menujukkan bahwa ada satu dari enam variabel independen yang digunakan yaitu current ratio, total assets turnover, debt ratio, return on assets, earning per share dan variabel dummy yang menjelaskan golongan ukuran aset perusahaan, yang berpengaruh signifikan terhadap pertumbuhan laba pada periode 2010-2013, yaitu return on assets. Model regresi yang dihasilkan dalam kahian ini menunjukkan bahwa secara simultan keenam variabel independen berpengaruh secara signifikan terhadap pertumbuhan laba perusahaan manufaktur periode 2010-2013.

\section{Referensi}

Ade Gunawan \& Sri Fitri Wahyuni. 2013. Pengaruh Rasio Keuangan terhadap Pertumbuhan Laba pada Perusahaan Perdagangan di Indonesia. Jurnal Manajemen dan Bisnis. 13 (1): 63-83

Agus Sabardi. 1995. Manajemen Keuangan Jilid 1. Yogyakarta: UPP AMP YKPN.

Brigham, Eugene F. \& Joel F. Houston. 2013. Manajemen Keuangan. Jakarta: Penerbit Erlangga.

Epri Ayu. 2007. Analisis Rasio Keuangan Untuk Memprediksi Laba. Thesis. Semarang: Program Study Magister Manajemen Program Pasca Sarjana Universitas Dopenogoro

http://eprint.undip.ac.id/17412/1Epri_Ayu_Hapsari.pdf [1Januari2013]

Imam Ghazali. 2005. Aplikasi Analisis Multivariate dengan Program Multivariate dengan Program SPSS. Semarang: Badan Penerbit Undip.

Moeljadi. 2006. Manajemen Keuangan (Pendekartan Kuantitatif dan Kualitatif) Jilid 1. Malang: Bayumedia Publishing.

Suprihatmi dan Wahyudin. 2003. "Pengaruh Rasio Keuangan Terhadap Kemampuan Memprediksi Perubahan Laba Pada PerusahaanPerusahaan Manufaktur yang terdaftar di Bursa Efek Jakarta”. Tidak Dipublikasikan. Tesis. Surakarta: Universitas Muhammadiyah Surakarta.

Warsidi Bambang \& Agus Pramuka. 2000. Evaluasi Kegunaan Rasio Keuangan dalam Memprediksi Perubahan Laba di Masa yang Akan Datang. Jurnal Akuntansi, Manajemen dan Ekonomi. 2 (1)

Widiasih Nur Ari. 2006. "Analisis Rasio Keuangan dalam Memprediksi Perubahan Laba pada Perusahaan Manufaktur yang Terdaftar di Bursa Efek Jakarta”. Tidak Dipublikasikan. Skripsi. Yogyakarta: Universitas Islam Indonesia.

Weston J.F., E.F. Brigham. Manajemen Keuangan. 1985. Jilid 2, Edisi 7, diterjemahkan oleh Djoerban Wahid. Jakarta: Erlangga. 